\title{
Disagreement and Legitimacy
}

\author{
Zoltan Miklosi • Andres Moles
}

Published online: 23 November 2013

(C) Springer Science+Business Media Dordrecht 2013

Disagreement in politics is ubiquitous. People disagree about what makes a life worthy or well-lived. They disagree about what they owe to each other in terms of justice. They also disagree about the proper manner of dealing with the consequences of disagreement. What is more, they disagree about the normative significance of moral and political disagreement. Disagreement has been, for at least three decades now, the focus of a series of major works in political philosophy. It has been called one of the fundamental 'circumstances of politics' by Waldron (1999). Rawls (1996) took disagreement to be at the heart of the problem of political legitimacy. Gerald Gaus takes it to be the most important task of liberal political theory to justify political institutions in the face of 'evaluative diversity' (Gauss 1996, 2011). For Thomas Christiano, disagreement is part of the basis of the authority of democracy (Christiano 2008).

Political institutions make decisions and rules that are binding for everyone and can be coercively enforced against all, whether or not they agree with the content of the decisions. Most political theorists agree that such institutions are necessary in order to achieve justice and secure the fundamental rights of individuals. Therefore, not having political institutions at all is neither empirically plausible nor morally attractive. However, the ubiquity of disagreement about the content of the decisions that political institutions ought to make raises the question of how binding decisions can be legitimately enforced, through the use of coercion if necessary, against morally competent and responsible people who disagree in good faith with those decisions, even after careful reflection and given willingness to consider the reasons offered in their favor. All the political theories that focus centrally on disagreement assume that good faith disagreement on at least some matters survives even if all participants are deliberating in good faith and are motivated to find common grounds. Full consensus is not an option. 
To be sure, disagreement generates a difficulty for justifying political institutions and policies only if we have reason to think that there is something prima facie morally problematic, at least under certain circumstances, about forcing (or threatening to force) morally competent people to perform certain acts or to comply with certain rules they sincerely disagree with. Most of the theorists who put disagreement at the center of the problem of political morality agree that there are such reasons, and the dominant line of reasoning is that it is disrespectful to the exercise of reason and judgment of individuals to compel them to live together on terms they do not accept, at least under certain circumstances. However, even those who endorse the general concern with respect for the reason of individuals often disagree about the force of this consideration or its place in the order of justification in political morality. Some treat respect for reason as a rock bottom principle of political morality, such that it provides especially strong reasons, or may even be lexically prior to all other considerations. This seems to be the view of many deliberative democrats (Cohen 1997) as well as of Waldron (1999). Others-Thomas Christiano for instance - argue that respect for reason is not a fundamental principle but is based on the more basic ideal of equal concern for well-being (Christiano 2000), and therefore it can be outweighed by other considerations (Christiano 2008, pp. 216-218). Nevertheless, even those who do not take respect for the exercise of reason as a fundamental or lexically prior principle agree that forcing people to live under terms of association that they reject in good faith is wrong or can undermine legitimacy unless certain procedures of decision-making and deliberation are in place that ensure a fair hearing to every view, including those that in the end remain in the minority.

Proposals to address the problem that disagreement causes for legitimacy may be arranged on a continuum between two characteristically different approaches. On the one hand, those who see respect for reason as an especially weighty, rockbottom consideration tend to favor an approach that, in the absence of the possibility of full consensus, seeks to achieve at least a limited consensus restricted to certain issues of basic justice. The suggestion is that in deliberating about the terms of political association, people should bracket the more controversial parts of their overall outlook and only propose principles that others may also accept, given their own views. This approach, different variants of which are known as political liberalism and public justification liberalism, places constraints on the reasons that may be proposed in justifying political institutions and decisions, thereby barring people from appealing to what they take to be the whole truth about the matters at hand. Proponents of this approach hold that political institutions can be legitimate only if they are based on principles that everyone subject to them can reasonably accept or cannot reasonably reject. In the last analysis, political liberalism and its relatives do not abandon the ideal of consensus that seems to be a natural implication of the principle of respect for reason, but instead seek to show that consensus on some fundamental matters is still possible at least between persons who are to some extent idealized to conform to the principle of reasonableness. The success of this strategy of accommodating disagreement depends, among other things, on the possibility of finding a level of idealization such that the idealized viewpoints still bear some significant degree of resemblance to their actual, real- 
world counterparts, but at the same time allow for enough consensus (for more on the problems of idealization, see Gauss 2011).

The strategy of political liberalism, thus, relies on a content-based restriction: only those decisions (regarding matters of basic justice) are legitimate that are supported by reasons that all (reasonable) people can accept. The hope is that this set of reasons will be both non-empty and sufficiently determinate to provide guidance for the design of basic institutions. The alternative strategy, pursued first and foremost by those who treat respect for the outcome of the exercise of individual reason as a derivative rather than fundamental principle, does not rely on content-based constraints on the reasons that are offered in justification. It suggests instead that respect for persons as free and equal is honored as long as decisionmaking procedures guarantee each competing view, whether or not it is in conformity with 'public reason,' a fair hearing and chance to carry the day, even if the outcome of the process will be unacceptable to some morally competent persons. In this manner, Dworkin (2000) argues that a very robust conception of free political speech, together with other democratic procedures, is a necessary condition of the legitimacy of binding collective decisions, because it gives an opportunity for the proponents of all views, without exception, to gain majority support. Christiano develops a similar defense of democratic procedures, arguing that they allow each person, including those who remain in the political minority, to see that their viewpoints have been taken seriously in the political process, and therefore can see themselves as being treated as equals (Christiano 2008). Both Dworkin and Christiano argue, though on different grounds, that their conception of democratic legitimacy is compatible with, or even requires, constraints on the ability of political majorities to impose decisions on the dissenting minority. This is where they part company with Waldron, another advocate of the broadly procedural strategy to deal with the problem of disagreement, who argues that the only legitimate manner of collective decision making in the face of disagreement is majority rule. In other words, proponents of the alternative approach hold that respect for the exercise of each person's reason is secured and expressed simply by giving each a fair say in the collective decision-making process, and, for that matter, by granting them extensive rights to lead their individual lives in light of their own reasons. One would express disrespect for reason only by withholding some or all democratic or liberal rights from some people (Christiano 2008, pp. 224-225).

The articles in this special issue all engage some of the problems that are raised by persistent and deep disagreement for justifying political institutions. Enzo Rossi's article, 'Legitimacy, democracy and public justification' addresses some of the intramural debates among those who share the general outlook that political structures can be legitimate only if they are supported by reasons that can be accepted by all suitably idealized (or 'reasonable') persons. Rossi's main goal is to identify the main normative commitment of political or public justification liberalism, and to evaluate Gaus' criticism of Rawls, as well as Gaus' own proposal, in light of that commitment. Rossi suggests that the fundamental liberal motivation for Rawlsian political liberalism's search for principles supported by reasons that all reasonable citizens can accept comes from a broadly voluntaristic conception of political legitimacy. In this view, political structures can be legitimate 
only if they are based, if not on the actual consent of citizens then at least on principles that are acceptable to them in the sense that it is possible for them to voluntarily act from these principles. This is why in Rawls' version of political liberalism the moral (rather than epistemic) ideal of reasonableness, understood as the willingness to find terms of political association that are mutually acceptable to all (similarly reasonable) citizens takes priority over substantive standards of justice in the justification of political arrangements. Gaus proclaims to share the fundamental rationale for political (or public justification) liberalism, and therefore rejects substantivist or correctness-based versions of liberalism which hold that successful justification of an outcome is not dependent on its being accepted by all (relevant) persons. However, Gaus criticizes Rawls' solution to the problem of reasonable disagreement because it sacrifices epistemic standards in order to achieve mutual acceptability, as it were. Gaus proposes to replace Rawls' acceptability requirement with that of accessibility, which requires only that suitably idealized persons can understand the principles proposed as the basis of political association as reasons, rather than that they can voluntarily act from those principles. However, this move, while possibly well-motivated, comes at a considerable cost from the point of view of the public justification project. Accessibility specified in this way, Rossi argues, does not have the element of voluntariness that acceptability, construed as above, retains, and therefore it cannot possess the legitimizing force of the former, at least as long as one understands the problem of liberal legitimacy in voluntaristic terms.

Rossi argues that the divergence between Rawls' political liberalism and Gaus' public justification liberalism can be traced to their different conception of autonomy. Rawls' notion (in Political Liberalism at any rate) has a more voluntaristic bent, while Gaus understands autonomy in a more Kantian, rationalistic sense, and this is why he gives priority to compliance with the demands of rationality over voluntariness. In his article, Rossi does not claim that by abandoning voluntariness Gaus' theory necessarily fails as a theory of normative justification as such. He merely claims that without the component of voluntariness it very nearly collapses into a correctness view of justification. Therefore, it fails not simpliciter, but only as a theory of public justification, or perhaps even as an attempt to combine a correctness theory with the theory of public justification.

Zoltan Miklosi's article, 'A puzzle about free speech, legitimacy, and countermajoritarian constraints,' explores some of the difficulties that arise in the context of the alternative strategy that was described above as broadly procedural. The main difficulty is internal to Dworkin's specific version of the strategy. Dworkin holds that under the circumstances of disagreement, it is a necessary condition of the legitimacy of binding political decisions that all those who disagree with them can fully state their dissent in public during the decision-making process, whether or not it is based on views that would pass as 'reasonable' according to adherents of political liberalism. Freedom of political speech, construed broadly to include hate speech, is necessary for legitimacy. This is the legitimacy argument for free speech. At the same time, Dworkin also holds that countermajoritarian practices such as the judicial review of political decisions made by an appropriately constituted political majority are justified. In this way, courts may block discriminatory laws backed by 
bigoted majorities. In Dworkin's view such practices are not only all-thingsconsidered justified but incur no moral costs because there are no important political ideals (such as political equality) that advise against them. This is what Miklosi refers to as the 'no moral costs thesis.' The article suggests that there is an important tension between the legitimacy argument for free speech and the no moral costs thesis. It argues that the most plausible construal of the legitimacy argument is that free political speech is a normatively special vehicle of forming political majorities. Political decisions can be legitimately enforced against members of dissenting minorities if their freedom of speech was not curtailed, because they had the opportunity to persuade a majority of their fellow citizens to support their views, and because they still have this opportunity as far as the future is concerned. At the same time, the main reason Dworkin offers in favor of the no moral costs thesis is that members of political majorities whose decisions are blocked by countermajoritarian constraints have no legitimate complaint on the ground that their political equality has been infringed, because each individual's influence on the outcome of collective decision-making is vanishingly small to begin with, and therefore a small further reduction in this already infinitesimally small share of political power cannot be the basis of any serious objection. However, Miklosi argues that this argument from insignificance, as he calls it, contradicts the main rationale of the legitimacy argument. It cannot be the case both that the individual right to free speech has vast legitimacy-conferring capacity due to its special role in forging new political majorities, and that individual political influence is so practically insignificant that some small subtraction from it has no normative significance whatsoever. An appreciation of the normative significance of individual political influence is at the heart of the legitimacy argument, but a dismissal of this very significance is purported to provide support for the no moral costs thesis. The conclusion that the paper draws from this tension is not that either the robust conception of free speech or countermajoritarian practices should be abandoned, but rather that the no moral costs thesis calls for reconsideration.

The next article also deals with issues of political equality. In 'Freedom, equality, minarets', Alexa Zellentin takes a novel approach to the 2009 referendum in Switzerland about the construction of new minarets in Swiss towns and cities. Most analyses of this referendum address the issue from the point of view of freedom of religion. The paper argues that this approach is not fully satisfactory because, in fact, the ban does not alter the way in which Islam is practiced in Switzerland. Zellentin's claim is, rather, that the ban threatens Muslims' fair value of political liberties. Drawing from Rawls, Zellentin argues that equal citizenship goes beyond mere equal formal rights of political participation: it also requires that political liberties have their 'fair value'. The idea is that political rights have a comparative element in the sense that their worth must be more or less the same for all citizens. Zellentin goes further than Rawls by claiming that the fair value of political rights involves not only limits on socioeconomic differences but also requires the reduction of inequalities due to other factors. In this case, it requires equal standing between different cultural groups. The paper explores three ways in which cultural differences might affect equal participation. First, some cultural minorities might be at a disadvantage because the form in which they interpret the political liberties at 
stake, or because they have less resources to reach all citizens in comparable terms than a person belonging to the majority group. For instance, it is harder for a candidate who speaks a minority language to reach the majority than a candidate who speaks the majority language. Second, minorities might suffer a disadvantage stemming from a cultural bias that favors the majority culture. This might be so because the majority's culture might set the standard according to which the minority's claims are interpreted. The third, and most important factor for Zellentin's argument, concerns the way in which minorities are perceived by the majority. The central claim of the paper is that the majority can disable a minority by sending a clear message that their views and claims are not equal. Banning the building of minarets is an example in which the majority of citizens (in this case, Swiss Christians) send a symbolic message to Swiss Muslims to the effect that they do not have equal standing. The main argument provides us with good reasons to explore forms of democratic legitimacy that do not depend (exclusively) on the majoritarian premise. In the last section of her paper, Zellentin explores some alternatives.

The next two articles address problems that unreasonable views or practices pose for liberal democracy. As we stated before, political disagreement plays a central role in Rawls' political liberalism. Unlike the procedural approach, he argues that political legitimacy requires that the use of coercive power be justified in a way that can be reasonably endorsed by citizens taken as free and equals (Rawls 1996, p. 137). Reasonable citizens will, according to him, endorse the idea of society as a fair system of social cooperation between free and equal citizens, and accept the 'burdens of judgment' (Rawls 1996 p. xliv; pp. 54-66). Rawls argues that securing an 'overlapping consensus' requires that citizens bracket controversial comprehensive values and appeal only to the political values that all reasonable citizens endorse (Rawls 1996, p. 15). In this way, Rawls' liberalism is purely political; it refrains from engaging with the truth of different comprehensive doctrines.

One pressing issue with Rawls' theory is that it is not entirely clear how reasonable citizens should treat those who reject basic liberal commitments. Rawls claims that unreasonable views must be contained 'like war and disease', but he fails to develop this point much further (Rawls 1996, p. 64, n. 19). In their article 'When God commands obedience: political liberalism and unreasonable religions', Matthew Clayton and David Stevens address the question of how political liberals should respond to religiously motivated disobedience. By this they mean individuals who believe that, if there is a conflict between liberal principles and the commands of God, they ought to follow the latter. This presents an acute problem for political liberals because they are committed to avoiding making judgments on the truth of any comprehensive doctrines. Although these citizens are unreasonable, it is not obvious what else liberals can say about them. A natural reply by liberals might be to refuse engaging with the unreasonable. However, the authors argue that other strategies might be more attractive. They suggest three different reasons for engagement. First, one way to undermine unreasonable views is to try and convince those who hold these views that they are mistaken. There is no reason why persuasion should not be part of the arsenal of containment (along with coercion and manipulation). Second, given that liberals believe that democratic institutions 
provide some goods that other regimes do not, liberals might have a duty to help others to see the benefits of living under shared liberal institutions. After all, part of the core of liberalism is a concern for the fate of our fellow citizens. If we can persuade them to join, why should we not? The third reason offered by Clayton and Stevens is that we should not be overtly optimistic about liberalism's ability to generate its own support over time. Although Rawls seems to be confident that it will, perhaps we should be more cautious. Engaging with the unreasonable might increase the likelihood of liberalism's stability.

Showing that there are good reasons for engagement is only part of the answer. The next question involves establishing the terms of such engagement. Clayton and Stevens pose this question as a dilemma. Either liberals keep their commitment to purely political values or they allow some (controversial) comprehensive doctrines to enter the picture. Notice, though, that if they do the former their engagement will, most likely, be futile. The most they can do is just to reiterate their belief that liberal values are weighty and important. But, crucially, this is the claim that the unreasonable reject. So, Clayton and Stevens conclude, liberals might need to adopt the latter strategy. The remaining part of their essay explains why this is still compatible with a modest view of political liberalism. Their claim is that, although normally political liberals will appeal to political values exclusively, in some circumstances they might need to appeal to some comprehensive truths.

A different aspect of the challenge that unreasonable views present for political liberalism is addressed in Andres Moles's 'The public ecology of freedom of association'. He argues that liberals have paid little attention to the fact that a part of citizens' attitudes and behavior might be shaped by processes circumventing their deliberative capacities. The main claim of this paper is that freedom of association can be legitimately constrained by a requirement of reasonability. Moles' argument has two parts. In the first one, he aims to show that unreasonable private associations have harmful effects that should worry liberals. The main idea is that these associations might threaten the exercise of the two moral powers that characterize liberal citizens: the ability to effectively exercise a sense of justice, and the ability to form, revise and pursue a conception of the good. One way to defend the claim that private associations are not unjust relies on the idea that the attitudes cultivated in the private sphere will pose no threat to the liberal character of the public sphere. This position is criticized by reference to findings in social psychology suggesting that spillover effects are likely to happen. Unreasonable associations, it is argued, are unjust in that they pass on and perpetuate sexist and racist stereotypes that have an impact in citizens' behavior and attitudes. Liberal citizens, Moles contends, must regret that sometimes they act in accordance with these stereotypes. Moreover, the paper argues that those who are made unable to associate on unreasonable terms are not wronged in any way. This is because liberal rights are conditional on being exercised in a reasonable way. The author defends a strong 'liberal congruence' thesis according to which citizens' private associations must be reasonable. The plausibility of this thesis depends on showing that an alternative account of freedom of association better protects the goods that associational rights and freedoms are supposed to protect. The paper argues that associational freedom is valuable for liberals because it promotes a variety of goods such as intimacy, the moral 
development of members, as well as a number of instrumental goals. Nevertheless, there is no reason to think that reasonable associations fare any worse with respect to the benefits of membership than unconstrained associations do. An implication of Moles' argument is that the site of the principles of political morality is broader than many liberals tend to accept.

\section{References}

Christiano, T. 2000. Waldron on law and disagreement. Law and Philosophy 19(4): 513-543.

Christiano, T. 2008. The constitution of equality. Oxford: Oxford University Press.

Cohen, J. 1997. Deliberation and democratic legitimacy. In Deliberative democracy, ed. J. Bohman, and W. Rehg, 67-91. Cambridge, MA: MIT Press.

Dworkin, R. 2000. Sovereign virtue. Cambridge, MA: Harvard University Press.

Gauss, G. 1996. Justificatory liberalism. Oxford: Oxford University Press.

Gauss, G. 2011. The order of public reason. Oxford: Oxford University Press.

Rawls, J. 1996. Political liberalism. New York: Columbia University Press.

Waldron, J. 1999. Law and disagreement. Oxford: Oxford University Press. 